\title{
Fecundity of Chub Mackerel (Scomber japonicus Houttuyn, 1782) in the Aegean Sea
}

\author{
Ö. Cengiz ${ }^{a *}$ \\ ${ }^{a}$ Faculty of Fisheries, Van Yüzüncü Y1l University, Van, Turkey \\ *e-mail: ozgurcengiz17@gmail.com
}

Received: November 6, 2019 - Accepted: December 2, 2019 - Distributed: May 31, 2021

(With 2 figures)

\begin{abstract}
This study was carried out in April - June 2014 to determine absolute fecundity (F) of the chub mackerel (Scomber japonicus Houttuyn, 1782) in Saros Bay (Aegean Sea, Turkey). The relations between the absolute fecundity and total length, total weight and age of the chub mackerel females were estimated as $\mathrm{F}=0.0318 \mathrm{TL}{ }^{4.81}, \mathrm{~F}=1573.9 \mathrm{TW}-42858$ and $\mathrm{F}=109607 \mathrm{~A}-136129$, respectively. This study aims to contribute to the reproductive biology of $S$. japonicus by reporting the first findings about the absolute fecundity of the species for the Aegean Sea.
\end{abstract}

Keywords: Scomber japonicus, fecundity, Saros Bay, Aegean Sea.

\section{Fecundidade da cavala (Scomber japonicus Houttuyn, 1782) no Mar Egeu}

\begin{abstract}
Resumo
Este estudo foi realizado em abril-junho de 2014 para determinar a fecundidade absoluta (F) da cavala (Scomber japonicus Houttuyn, 1782) na Baía de Saros (Mar Egeu, Turquia). As relações entre a fecundidade absoluta e comprimento total, peso total e a idade da cavala fêmeas foram estimados como $\mathrm{F}=0.0318 \mathrm{TL}^{4.81}, \mathrm{~F}=1573.9 \mathrm{TW}-42858$ e $\mathrm{F}=109607 \mathrm{~A}-136129$, respectivamente. Este estudo visa contribuir para a biologia reprodutiva de S. japonicus, apresentando as primeiras conclusões sobre a fecundidade absoluta das espécies para o Mar Egeu.
\end{abstract}

Palavras-chave: Scomber japonicus, fecundidade, Baía de Saros, Mar Egeu.

\section{Introduction}

Fecundity studies are of great importance in total population assessments, productivity and population dynamics studies, and the determination of the specific properties of the populations, subpopulations, and/or fish stocks (De Martini and Sikkel, 2006).

The chub mackerel (Scomber japonicus Houttuyn, 1782) is a cosmopolitan middle-sized pelagic species inhabiting warm and temperate costal waters of the Atlantic, Indian, and Pacific oceans and adjacent seas. It is found in the continental slope from the surface to the depth of $300 \mathrm{~m}$ and reaches its deepest levels during the day (Collette and Nauen, 1983). By virtue of its commercial importance worldwide, many studies has been conducted regarding growth and reproduction (Techetach et al., 2010; Cikeš Keč and Zorica, 2012; Cerna and Plaza, 2014), weight-length relationships (Petrakis and Stergiou, 1995; Moutopoulos and Stergiou, 2002; Karakulak et al., 2006), fishery (Cengiz et al., 2013a), feeding habit (Castro, 1993) and hermaphroditism (Özekinci et al., 2009), as a summary.

The objectives of the present study were: (1) to contribute to the reproductive biology of $S$. japonicus by reporting the first findings about the absolute fecundity of the species for the Aegean Sea and (2) to compare these results with those of the previous studies.

\section{Material and Methods}

Saros Bay, which is situated in the Northeastern Aegean Sea, is connected to the North Aegean with a depth of approximately $600 \mathrm{~m}$ to the west. The shelf extends at a water depth of 90-120 m. The length of the bay is about $61 \mathrm{~km}$ and the width at the opening to the Aegean Sea is about $36 \mathrm{~km}$ (Eronat and Sayin, 2014). Cengiz (2012) reported that the spawning period of the chub mackerel occurred between April and August with a peak in June in the Saros Bay. Therefore, 35 fully mature females $S$. japonicus were sampled with handline during the spawning season in 2014 (Figure 1).

The specimens were measured to the nearest $1 \mathrm{~mm}$ (total length, TL), weighed to the nearest $0.01 \mathrm{~g}$ (total weight). Following removal, the sagittal otoliths were first soaked in 5\% HCL and 3\% $\mathrm{NaOH}$ solutions, respectively, and washed in distilled water and subsequently dried. The sagittal otoliths, placed in watch glass filled with the water, were read using a stereoscopic zoom microscope 


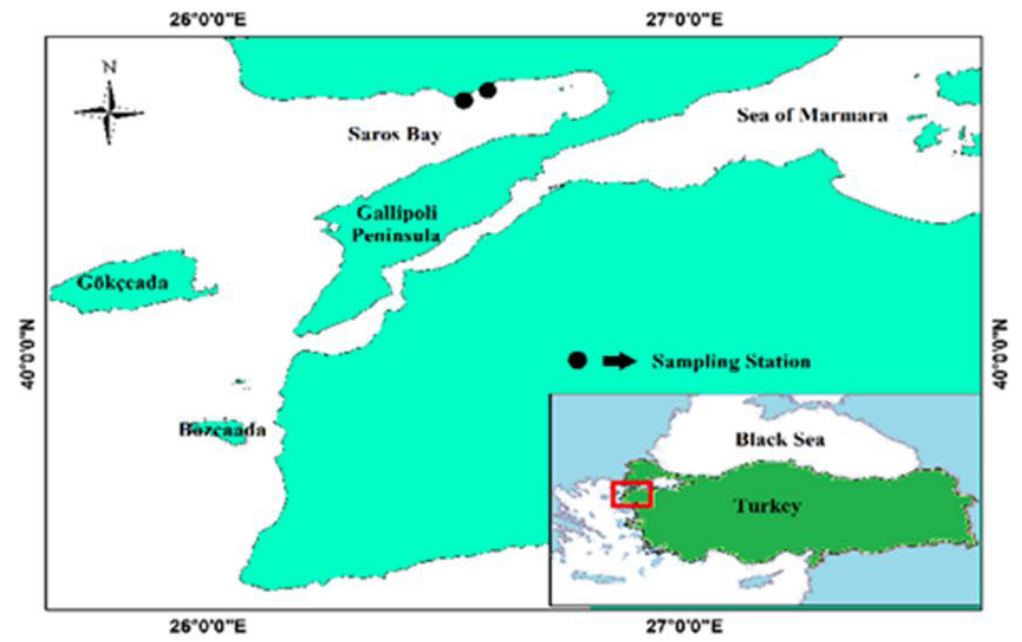

Figure 1. Saros Bay and sampling station.

under reflected light against a black background. Opaque and transparent zones were counted; one opaque zone plus one transparent zone was assumed to be one year (Cengiz et al., 2013b). Gravimetric method was used for fecundity estimates (Bagenal and Braum, 1978). In order to calculate fecundity, the ovaries of mature females (prior to the reproductive period) were weighed the nearest $0.0001 \mathrm{~g}$ (total weight), three sub-samples were taken from the front, mid- and rear sections of each ovary, weighed and then immersed seperately in Gilson's fluid. These ovaries were frequently shaken to ensure the separation of oocytes from ovarian tissues. All oocytes were counted directly under stereoscopic zoom microscope. The total number of eggs in each ovary sub-sample was then estimated by using the equation provided by Yeldan and Avşar (2000): $\mathrm{F}_{1}=\left(\mathrm{W}_{\mathrm{g}} \times \mathrm{N}\right) \times \mathrm{W}_{\mathrm{s}}^{-1}$, where $\mathrm{F}_{1}$ is the total number of eggs in ovary sub-sample $1, \mathrm{~W}_{\mathrm{g}}$ is the gonad weight, $\mathrm{N}$ is the number of eggs in the sub-sample, and $\mathrm{W}_{\mathrm{s}}$ is sub-sample weight. Later, by taking the mean number of three sub-sample fecundities $\left(\mathrm{F}_{1}, \mathrm{~F}_{2}\right.$, and $\left.\mathrm{F}_{3}\right)$, the absolute fecundity $(\mathrm{F})$ for each female fish was estimated as: $\mathrm{F}=\left(\mathrm{F}_{1}+\mathrm{F}_{2}+\mathrm{F}_{3}\right)^{-3}$. Hereby, the relations between absolute fecundity (F) and total length (TL), absolute fecundity (F) and total weight (TW), as well as absolute fecundity (F) and age (A) were estimated as $\mathrm{F}=\mathrm{aTL}^{\mathrm{b}}, \mathrm{F}=\mathrm{a}+\mathrm{bTW}$ and $\mathrm{F}=\mathrm{a}+\mathrm{bA}$, respectively, where $a$ and $b$ are the parameters of the equation (Avsar, 2005).

\section{Results and Discussion}

The absolute fecundity (F) was estimated for 35 ripe females (age 2 to 4) caught in April-June 2014. A maximum value of 350622 eggs was recorded in 4 year-olds fish weighing

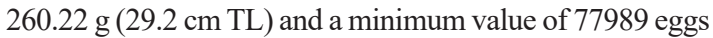
for 2 year-olds fish weighing $69.36 \mathrm{~g}(20.7 \mathrm{~cm} \mathrm{TL})$. The mean value \pm standard error of absolute fecundity was $177035 \pm 14645$. The relations between the absolute fecundity and total length, total weight and age of the chub mackerel females were estimated as $\mathrm{F}=0.0318 \mathrm{TL}^{4.81}, \mathrm{~F}=1573.9 \mathrm{TW}-42858$ and $\mathrm{F}=109607 \mathrm{~A}-136129$, respectively (Figure 2).
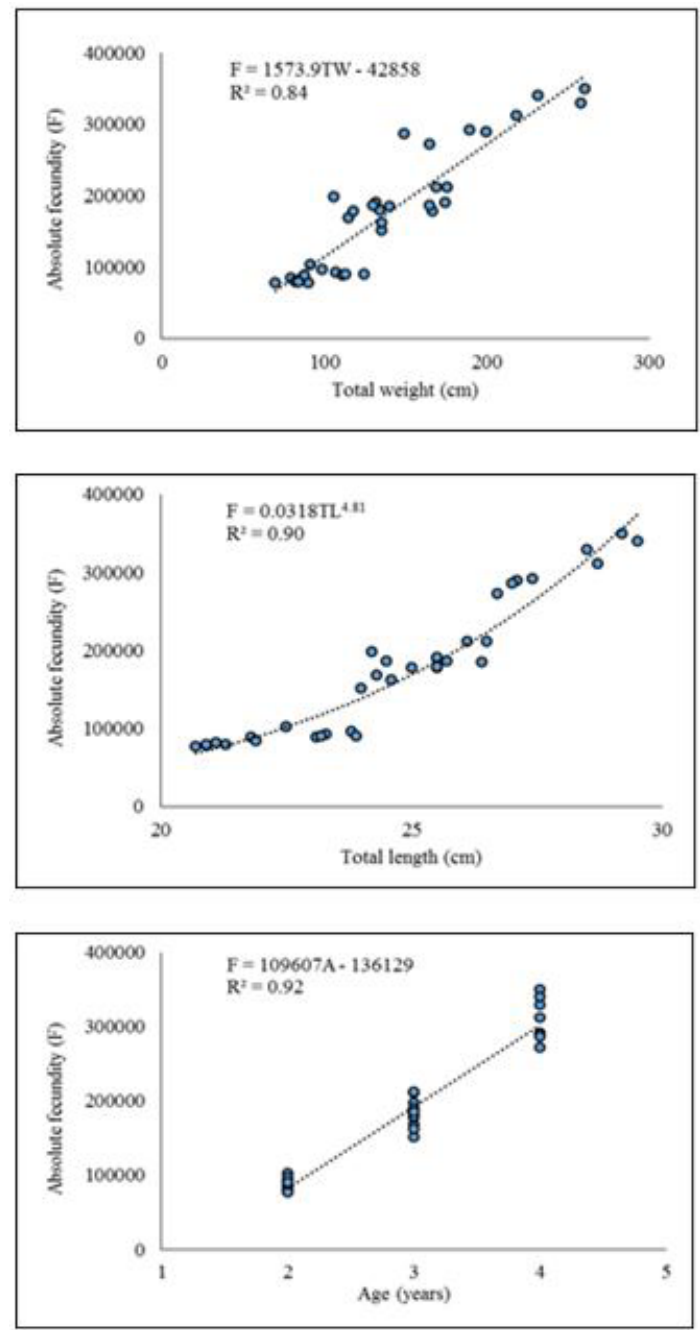

Figure 2. The relations between the absolute fecundity and total length, total weight and age of the chub mackerel females, Scomber japonicus, from Saros Bay. 
Table 1. The fecundity values of Scomber japonicus in different areas.

\begin{tabular}{cccccc}
\hline Author (s) & Area & F & BF & RF & Fish Length \\
\hline $\begin{array}{c}\text { Dickerson et al. } \\
(1992)^{*}\end{array}$ & California & - & 68.400 & 168 & $30.0-34.0$ \\
$\begin{array}{c}\text { Yamada et al. } \\
(1998)^{*}\end{array}$ & Izu Islands, Japan & - & $(23.280-120.537)$ & $(53.1-315)$ & $32.9-39.3$ \\
Techetach et al. & Larache, Morocco & 285.704 & 89.200 & 158 & $20.5-31.4$ \\
$(2010)^{*}$ & & $(77.621-465.712)$ & - & - \\
Cikeš Keč and & Eastern Adriatic Sea & 181.277 & - & - \\
Zorica (2012)* & & $(99.166-394.120)$ & & $21.2-34.6$ \\
This study & Saros Bay, Aegean Sea & 177.035 & - & - \\
& & & & $20.7-29.2$ \\
\end{tabular}

*from Techetach et al. (2019); F, absolute fecundity; BF, batch fecundity; RF, relative fecundity.

Table 1 presents the fecundity values of Scomber japonicus in different areas.

Within a given species, fecundity may vary as a result of different adaptations to enviromental habitats (Witthames et al., 1995). Even within a stock, fecundity is known to vary annually, undergo long-term changes (Rijnsdorp, 1991). However, the fecundity-size relations has been used principally as a rapid means of predicting the fecundity of fish (Dulčić et al., 1998). Consequently, the results of this study will increase the life history data available for $S$. japonicus by providing the scientific support required so as to identify the current stock state and will help conservation and management of the species.

\section{Acknowledgements}

The author would like to thank the fisherman Engin TUNÇ and Semih KALE for their supports.

\section{References}

AVSAR, D., 2005. Fisheries biology and population dynamics. Adana: Nobel Press, 332 p.

BAGENAL, T.B. and BRAUM, E., 1978. Eggs and early life history. In: T. BAGENAL, ed. Methods for assessment of fish production in freshwaters. Oxford: Blackwell Scientific, $106 \mathrm{p}$.

CASTRO, J.J., 1993. Feeding ecology of chub mackerel Scomber japonicus in the Canary Islands area. South African Journal of Marine Science, vol. 13, no. 1, pp. 323-328. http://dx.doi. org/10.2989/025776193784287400.

CENGIZ, O., 2012. Age, growth, mortality and reproduction of the chub mackerel (Scomber japonicus Houttuyn, 1782) from Saros Bay (Northern Aegean Sea, Turkey). Turkish Journal of Fisheries and Aquatic Sciences, vol. 12, pp. 799-809. http:// dx.doi.org/10.4194/1303-2712-v12 408 .

CENGIZ, O., AYAZ, A., OZEKINCI, U., OZTEKIN, A. and KUMOVA, C. 2013a. Determination of hook selectivity used for catching the Chub mackerel (Scomber japonicus Houttuyn, 1782) in Dardanelles and Gallipoli Peninsula (North-eastern Mediterranean, Turkey). Menba Journal of Fisheries Faculty, vol. 1 , no. 1 , pp. 22-27.

CENGIZ, O., OZEKINCI, U., ISMEN, A. and OZTEKIN, A., 2013b. Age and growth of the four-spotted megrim (Lepidorhombus boscii Risso, 1810) from Saros Bay (Northern Aegean Sea, Turkey).
Mediterranean Marine Science, vol. 14, no. 1, pp. 36-44. http:// dx.doi.org/10.12681/mms.328.

CERNA, F. and PLAZA, G., 2014. Life history parameters of chub mackerel (Scomber japonicus) from two areas off Chile. Bulletin of Marine Science, vol. 90, no. 3, pp. 833-848. http:// dx.doi.org/10.5343/bms.2013.1077.

CIKEŠ KEČ, V. and ZORICA, B., 2012. The reproductive traits of Scomber japonicus (Houttuyn, 1782) in the Eastern Adriatic Sea. Journal of Applied Ichthyology, vol. 28, no 1, pp. 15-21. https://doi.org/10.1111/j.1439 0426.2011.01893.x.

COLLETTE, B.B. and NAUEN, C.E., 1983. FAO species catalogue. Scombrids of the world. An annotated and illustrated catalogue of tunas, mackerels, bonitos and related species known to date. Rome: FAO, 137 p. FAO Fisheries Synopsis, no. 125

DE MARTINI, E. and SIKKEL, P., 2006. The ecology of marine fishes: california and adjacent waters. Berkeley: University of California Press, pp. 482-523.

DICKERSON, T., MACEWICZ, B.J. and HUNTER, J.R., 1992. Spawning frequency and batch fecundity of chub mackerel Scomber japonicus, during 1985. California Cooperative Oceanic Fisheries Investigations Reports, vol. 33, pp. 130-140.

DULČIĆ, J., SKAKELJA, N., KRALJEVIĆ, M. and CETINIĆ, P., 1998. On the fecundity of the Black Sea bream, Spondyliosoma cantharus (L.), from the Adriatic Sea (Croatian coast). Scientia Marina, vol. 62, no. 3, pp. 289-294. http://dx.doi.org/10.3989/ scimar.1998.62n3289.

ERONAT, C. and SAYIN, E., 2014. Temporal evolution of the water characteristics in the bays along the eastern coast of the Aegean Sea: Saros, İzmir, and Gökova bays. Turkish Journal of Earth Sciences, vol. 23, pp. 53-66. http://dx.doi.org/10.3906/yer-1307-4.

KARAKULAK, F.S., ERK, H. and BILGIN, B., 2006. Lengthweight relationships for 47 coastal fish species from the Northern Aegean Sea, Turkey. Journal of Applied Ichthyology, vol. 22, no. 4, pp. 274-278. http://dx.doi.org/10.1111/j.1439-0426.2006.00736.x.

MOUTOPOULOS, D.K. and STERGIOU, K.I., 2002. Length-weight and length-length relationships of fish species from the Aegean Sea (Greece). Journal of Applied Ichthyology, vol. 18, no. 3, pp. 200-203. http://dx.doi.org/10.1046/j.1439-0426.2002.00281.x.

OZEKINCI, U., AYAZ, A., ALTINAGAC, U., CENGIZ, O. and OZTEKIN, A., 2009. A hermatophroditic specimen of Chub mackerel Scomber japonicus in the Dardanelles, Turkey. Journal of Animal and Veterinary Advances, vol. 8, no. 9, pp. 1798-1799.

PETRAKIS, G. and STERGIOU, K.I., 1995. Weight-length relationships for 33 fish species in Greek waters. Fisheries Research, 
vol. 21, no. 3-4, pp. 465-469. http://dx.doi.org/10.1016/01657836(94)00294-7.

RIJNSDORP, A.D., 1991. Changes in fecundity of female North Sea plaice (Pleuronectes platess $\mathrm{L}$ L.) between three periods since 1990. ICES Journal of Marine Science, vol. 48, no. 3, pp. 253280. http://dx.doi.org/10.1093/icesjms/48.3.253.

TECHETACH, M., AJANA, R. and SAOUD, Y., 2019. Reproductive parameters of Atlantic chub mackerel Scomber colias in M'diq Bay, Morocco. Journal of the Marine Biological Association of the United Kingdom, vol. 99, no. 4, pp. 957-962. http://dx.doi. org/10.1017/S0025315418000930.

TECHETACH, M., HERNANDO-CASAL, J.A., SAOUD, Y. and BENAJIBA, M.H., 2010. Reproductive biology of chub mackerel Scomber japonicus in Larache area, Moroccan North Atlantic coast. Cybium, vol. 34, no. 2, pp. 159-165.
WITTHAMES, P.R., GREER WALKER, M., DINIS, M.T. and WHITING, C.L., 1995. The geographical variation in the potential annual fecundity of Dover sole, Solea solea (L.) from European shelf waters during 1991. Netherlands Journal of Sea Research, vol. 34, no. 1-3, pp. 45-58. http://dx.doi.org/10.1016/00777579(95)90013-6.

YAMADA, T., AOKI, I. and MITANI, I., 1998. Spawning time, spawning frequency and fecundity of Japanese chub mackerel, Scomber japonicus in the waters around the Izu Islands, Japan. Fisheries Research, vol. 38, no. 1, pp. 83-89. http://dx.doi. org/10.1016/S0165-7836(98)00113-1.

YELDAN, H. and AVSAR, D., 2000. A preliminary study on the reproduction of the rabbitfish (Siganus rivulatus Forsskal, 1775) in northeastern Mediterranean. Turkish Journal of Zoology, vol. 24, pp. 173-182. 